\title{
Differences in Body Composition between Water Polo Players of National Teams of Montenegro and Croatia Participating in the European U15 Championship 2019
}

\author{
Diferencias en la Composición Corporal entre los Jugadores de Waterpolo de las Selecciones \\ Nacionales de Montenegro y Croacia Participantes en el Campeonato Europeo U15 2019
}

Jovan Gardasevic ${ }^{1}$; Dusko Bjelica ${ }^{1} \&$ Ivan Vasiljevic $^{1}$

GARDASEVIC, J.; BJELICA, D. \& VASILJEVIC, I. Differences in body composition between water polo players of national teams of Montenegro and Croatia participating in the European U15 Championship 2019. Int. J. Morphol., 38(3):720-725, 2020.

SUMMARY: The aim of this research was to determine the differences between the cadets (U15) water polo players of national teams of Montenegro and Croatia in the body composition and anthropometric characteristics. A sample of 32 subjects was divided into two sub-samples. The first sub-sample of the subjects was consisted of 16 water polo players of Montenegro national team of the average age 14.69土.48, the vice champions on the European Championships in Burgas (Bulgaria) 2019, while the other sub-sample was consisted of 16 water polo players of national team of Croatia of the average age of 14.75 \pm .45 , who occupied the eighth position on the European Championships in Burgas (Bulgaria) 2019. Water polo players were tested at the final preparations just before the European championship. Body composition and anthropometric characteristics were evaluated by a battery of 11 variables: body height, body weight, triceps skinfold, biceps skinfold, skinfold of the back, abdominal skinfold, upper leg skinfold, lower leg skinfold, body mass index, fat percentage and muscle mass. The standard central and dispersion parameters of all variables were calculated. The significance of the differences between the water polo players of two national teams in the variables for assessing body composition and anthropometric characteristics was determined by a t-test for independent samples. It was found that there are statistically significant differences in five variables, in three variables at $\mathrm{p}<0.01$ (body height, triceps skinfold and biceps skinfold), and in two variables at $\mathrm{p}<0.05$ (upper leg skinfold and muscle mass). It can be stated that the water polo players of Montenegro have statistically significantly higher triceps skinfold, biceps skinfold and upper leg skinfold, and statistically significantly lower body height and muscle mass than the water polo players of Croatia.

KEY WORDS: Montenegrin water polo players; Croatian water polo players; Body composition.

\section{INTRODUCTION}

Water polo is popular sport worldwide. It is a highly dynamic and fast team game which, with its richness of movement, falls under the category of polystructural sports games. Water polo is a sport characterized by numerous and various complex and dynamic a contact sport characterized by different swimming intensities, dueling, acceleration and deceleration (Gardasevic et al., 2019c). In water polo, top score can be achieved only under conditions of wellprogrammed training process. High quality management of the training process depends on the knowing of the structure of certain anthropological capabilities and water polo player's characteristics, as well as their development. Various researches are to be carried out to establish certain principles and norms for the transformational processes of the anthropological characteristics important for water polo; with anthropometric characteristics and body composition among them as expected. Findings regarding anthropometric characteristics and body composition are of crucial importance for complex sports games such as water polo. The anthropometric space is defined by the longitudinal dimension of the skeleton, the transversal dimensionality of the skeleton, the mass and volume of the body. The purpose of knowing anthropometric characteristics is to improve skills in many sports (Carter \& Heath, 1990). The anthropometric status of top level athletes is relatively homogeneous, depending on the sport, and it can be defined as a model of athletic achievement. Research on anthropometric characteristics and body composition among athletes of different sports indicates that athletes of different sports have their own specific characteristics (Popovic et al., 2013; Bjelica et al., 2019), mostly due to the reason that absolute size contributes a significant percentage of total variance associated with athletic success (Carvajal et al., 2012). Muscle mass improves performance in activities that require muscular strength and

${ }^{1}$ University of Montenegro, Faculty for Sport and Physical Education, Narodne omladine bb, 81400 Niksic, Montenegro. 
endurance, but also in those that require enviable aerobic ability (Rico-Sanz, 1998).

It is well known that water polo in Montenegro and Croatia has a long tradition and the best results in international competitions. Montenegrins and Croats were the champions of Europe at both clubs and national team's level. Also, young age national teams are always in the European and World top. It was expected that both national teams will continue with good results on the cadets (U15) European Championships in Burgas (Bulgaria) 21-28 July 2019, where sixteen national teams participated. It is clear, these are the best selected players in Montenegro and Croatia, at age 15. It is certain that they have had many years of quality training process to deserve to wear a representative cap. It is well known in all sports and therefore in water polo that only long-term and intensive training is the one that allows to reach the elite representative level and remain in the elite selection (Gardasevic et al., 2019b). It became as interesting for researchers to determine the models of body composition and anthropometric characteristics of the water polo players who play for these two national teams as to determine the differences among them.

The aim of this research was to determine body composition and anthropometric characteristics of cadets (U15) water polo players of national teams of Montenegro and Croatia, who participated on the European Championships in Burgas (Bulgaria) 2019. Afterwhich, compared the variables between these water polo players and determined the possible differences between them.

\section{MATERIAL AND METHOD}

The data obtained in the study of body composition and anthropometric characteristics were checked and prepared for processing according to the set goal. Data bases were arranged according to the features and prepared for planned statistical processing. The results obtained by statistical analysis were presented in the tables and analyzed by the corresponding logical units. In general, the results of the research, through gradual aspect of individual relationships, allow seeing differences in the observed anthropometric measures and body composition in accordance with the aim of the research. That is, they contribute to a clearer application of the obtained results in practice. In terms of time constraint, the research is of transversal character, and it consists of a one-off measurement of the corresponding body composition and anthropometric characteristics of cadets (U15) water polo players.

Sample of subjects. A sample of the subjects consists of a total of 32 water polo players, divided into two sub-samples.
The first sub-sample of the subjects was consisted of 16 water polo players of Montenegro national team of the average age 14.69 .48 , the vice champions on the European Championships in Burgas (Bulgaria) 2019, while the other sub-sample was consisted of 16 water polo players of national team of Croatia of the average age of 14.75 \pm .45 , who occupied the eighth position on the European Championships in Burgas (Bulgaria) 2019 (Table I). Water polo players of both national teams were tested at the joint final preparations in Niksic (Montenegro), one week before the European championship have been held in Bulgaria.

Table I. Final rankings (28.07.2019) at the European U15 water polo Championships, Burgas (Bulgaria) 2019.

\begin{tabular}{llc}
\hline National teams & Place \\
\hline & Hungary & 1 \\
& Montenegro & 2 \\
& Italy & 3 \\
& Greece & 4 \\
& Serbia & 5 \\
& Georgia & 6 \\
& Spain & 7 \\
& Croatia & 8 \\
& Russia & 9 \\
& Slovakia & 10 \\
& Slovenia & 11 \\
& Turkey & 12 \\
& Romania & 13 \\
& Bulgaria & 14 \\
& Netherlands & 15 \\
\hline & Belarus & 16 \\
\hline
\end{tabular}

Sample of measures. Anthropometric research has been carried out with respect to the basic rules and principles related to the selection of measuring instruments and measurement techniques standardized in accordance with the International Biological Program guidelines. For the purpose of this study, 8 anthropometric measures have been taken: body height, body weight, triceps skinfold, biceps skinfold, skinfold of the back, abdominal skinfold, upper leg skinfold and lower leg skinfold and 3 body composition assessment variables: body mass index, fat percentage and muscle mass. Anthropometer, caliper, and measuring tape were used for anthropometric measurements. To evaluate the body composition, Tanita body fat scale - model BC-418MA, was used. The principle of this scale is based on indirect measurement of the body composition; a safe electrical signal is transmitted through the body via electrodes located in the standalone unit. The Tanita Scale, thanks to its athletics mode, enables athletes to closely monitor their body weight, health condition and form with all relevant parameters.

Method of data processing. The data obtained through the research were processed by descriptive and comparative 
statistical procedures. For each variable, central and dispersion parameters, as well as asymmetry and flattening measures were processed. Differences in anthropometric characteristics and the composition of the body of the players of these two clubs were determined by using a discriminatory parametric procedure with t-test for small independent samples, with statistical significance of $\mathrm{p}<0.05$.

\section{RESULTS}

In Tables II and III, basic descriptive statistical parameters of anthropometric variables and body composition of the water polo players of the two national teams, where the values of central measurements and dispersion tendencies were calculated, are shown: Arithmetic mean (Mean), Standard deviation (Std.D.), Variance (Variance), Minimal (Min) i Maximal (Max) values, coefficient of Curvature (Skewness) and Elongation (Kurtosis). First, the central and dispersion parameters of the variables were analyzed to evaluate body composition and anthropometric characteristics of the water polo players of Montenegro (Table II).
Based on the central and dispersion parameters, the values of the skewness and the kurtosis, it can be noted that almost all the variables are placed within the normal distribution boundaries. It could be based on the value of skewness as well, that the one variable body mass index has mild asymmetry, and though not statistically significant on behalf of better results, there is a positive sign. By the value of the kurtosis, it can be noticed that the body mass index has a statistically significant leptokurticity, which indicates that a greater number of results in this variable are arranged around the arithmetic mean. Body height and triceps skinfold have a statistically significant platikurticity, which indicates that a greater number of results in this variable are arranged to the ends of the Gaus curve. In conclusion, according to all statistical parameters, it can be stated that we have good selection water polo players U15; that there is a normal distribution in almost all variables and that the results that prevail are superior to the arithmetic mean, which is not statistically significant because it is to be expected that regarding water polo national team members, there is no too large a span between the results of analyzed variables.

Based on the central and dispersion parameters of the water polo players of Croatia (Table III), it can be stated that

Table II. Central and dispersion parameters of variables for assessment of body composition and anthropometric characteristics of Water polo players of Montenegro $(\mathrm{N}=16)$.

\begin{tabular}{lcccccc}
\hline Variables & Min & Max & Mean \pm S.D. & Variance & Skewness & Kurtosis \\
\hline body height & 172.5 & 188.5 & $179.19 \pm 5.45$ & 29.671 & .546 & -1.227 \\
body weight & 59.9 & 93.3 & $72.25 \pm 9.09$ & 82.635 & .961 & .931 \\
triceps skinfold & 6.4 & 13.6 & $10.44 \pm 2.25$ & 5.072 & -.359 & -1.091 \\
biceps skinfold & 4.9 & 12.7 & $8.35 \pm 2.19$ & 4.783 & .281 & -.206 \\
skinfold of the back & 5.8 & 18.6 & $10.23 \pm 3.43$ & 11.769 & .855 & .698 \\
abdominal skinfold & 6.4 & 29.0 & $14.83 \pm 6.93$ & 47.974 & .964 & .152 \\
upper leg skinfold & 5.8 & 21.2 & $14.38 \pm 4.55$ & 20.736 & -.372 & -.124 \\
lower leg skinfold & 4.0 & 16.0 & $9.19 \pm 3.58$ & 12.827 & .356 & -.473 \\
body mass index & 19.3 & 27.6 & $22.42 \pm 1.98$ & 3.931 & 1.039 & 1.981 \\
fat percentage & 12.2 & 20.7 & $16.71 \pm 2.22$ & 4.917 & -.454 & -.167 \\
muscle mass & 28.8 & 41.9 & $33.98 \pm 3.59$ & 12.906 & .993 & .678 \\
\hline
\end{tabular}

Table III. Central and dispersion parameters of variables for assessment of body composition and anthropometric characteristics of water polo players of Croatia ( $\mathrm{N}=16)$.

\begin{tabular}{lcccccc}
\hline V ariables & Min & Max & Mean \pm S.D. & Variance & Skewness & Kurtosis \\
\hline body height & 179.7 & 194.5 & $185.96 \pm 3.70$ & 13.725 & .645 & 1.018 \\
body w eight & 65.5 & 86.0 & $75.84 \pm 6.22$ & 38.685 & .230 & -.652 \\
triceps skinfold & 4.0 & 11.8 & $8.00 \pm 2.14$ & 4.572 & -.300 & -.317 \\
biceps skinfold & 4.6 & 11.2 & $6.04 \pm 1.64$ & 2.688 & 2.267 & 6.345 \\
skinfold of the back & 6.6 & 19.0 & $10.29 \pm 3.24$ & 10.479 & 1.487 & 2.211 \\
abdominal skinfold & 7.6 & 25.4 & $12.23 \pm 4.52$ & 20.390 & 1.792 & 4.130 \\
upper leg skinfold & 8.3 & 18.0 & $11.40 \pm 2.90$ & 8.439 & 1.038 & -.007 \\
lower leg skinfold & 6.2 & 15.0 & $9.37 \pm 2.67$ & 7.121 & .993 & .382 \\
body mass index & 18.1 & 25.3 & $21.94 \pm 1.93$ & 3.735 & -.243 & -.245 \\
fat percentage & 13.0 & 18.7 & $15.47 \pm 1.63$ & 2.662 & .397 & -.105 \\
muscle mass & 31.5 & 41.0 & $36.56 \pm 2.61$ & 6.816 & -.126 & -.273 \\
\hline
\end{tabular}


the values all the variables are very similar to those of the water polo players of Montenegro.

By the value of the skewness, it can be noticed that in the variables of the triceps skinfold, biceps skinfold, skinfold of the back, abdominal skinfold, there was a slight inclination on the side of the lower results, which is good because subcutaneous fat is a disrupting factor for athletes. The values of the kurtosis of variables of the body height and skinfold of the back form a slight leptokurtic curve, while two variables of the biceps skinfold and abdominal skinfold form a significant leptokurtic curve.

In order to determine whether there are statistically significant differences in the analyzed variables in the water polo players of these two national teams, participants of European U15 water polo Championships in Burgas (Bulgaria) 2019, the statistical procedure t-test (Table IV) was applied.

Based on the obtained values of t-test results, it can be noted that there are statistically significant differences in five variables; in three variables at $\mathrm{p}<0.01$ (body height, triceps skinfold and biceps skinfold), and in two variables at $\mathrm{p}<0.05$ (upper leg skinfold and muscle mass). It can be stated that the water polo players of Montenegro have statistically significant higher triceps skinfold, biceps skinfold and upper leg skinfold, and statistically significant lower body height and muscle mass than the water polo players of Croatia (Fig. 1). In all other variables the differences are negligible and not statistically significant.

In all other variables the differences are negligible and not statistically significant.
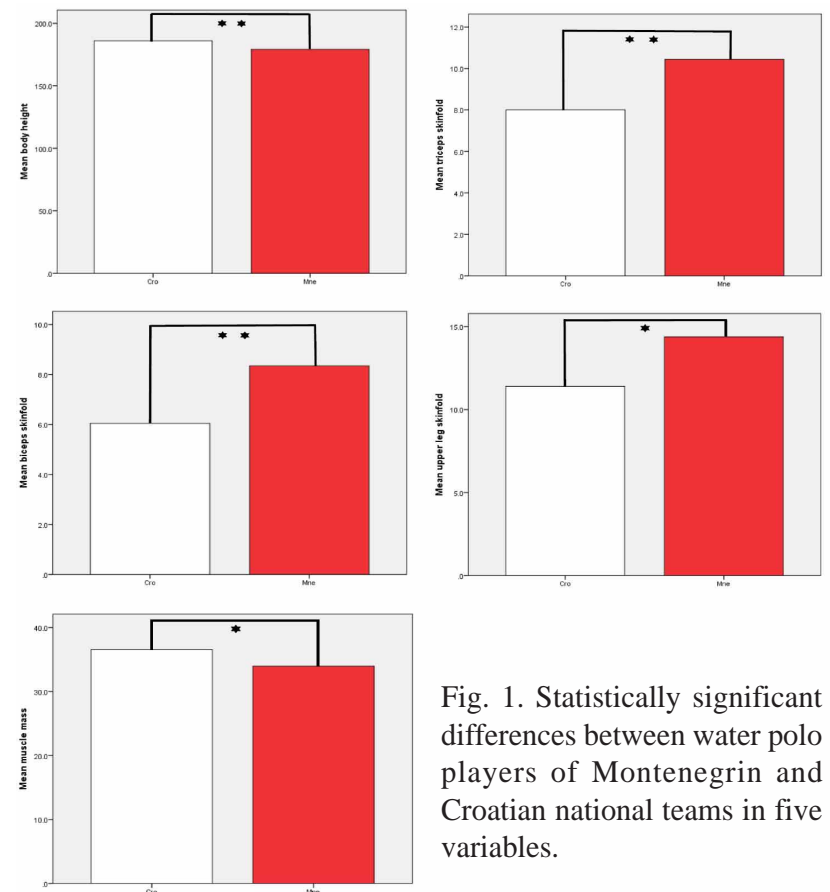

Fig. 1. Statistically significant differences between water polo players of Montenegrin and Croatian national teams in five variables.

Legend: Cro - Croatian national team; Mne - Montenegrin national team; ** $\mathrm{p}<.01 ; *-\mathrm{p}<.05$

Table IV. T-test values between the arithmetic mean of variables for the evaluation of body composition and anthropometric characteristics of water polo players of national team of Montenegro $(\mathrm{N}=16)$ and of national team of Croatia $(\mathrm{N}=16)$

\begin{tabular}{|c|c|c|c|c|c|}
\hline Variables & National team & Mean \pm S.D. & t-test & Sig. & Mean Diff. \\
\hline body height & $\begin{array}{c}\text { Monten egro } \\
\text { Croatia }\end{array}$ & $\begin{array}{l}179.19 \pm 5.45 \\
185.96 \pm 3.70\end{array}$ & -4.114 & $.000 * *$ & -6.7750 \\
\hline body weight & $\begin{array}{l}\text { Monten egro } \\
\text { Croatia }\end{array}$ & $\begin{array}{r}72.25 \pm 9.09 \\
75.84 \pm 6.22\end{array}$ & -1.303 & .203 & -3.5875 \\
\hline triceps skinfold & $\begin{array}{l}\text { Monten egro } \\
\text { Croatia }\end{array}$ & $\begin{array}{r}10.44 \pm 2.25 \\
8.00 \pm 2.14\end{array}$ & 3.140 & $.004 * *$ & 2.4375 \\
\hline biceps skinfold & $\begin{array}{l}\text { Monten egro } \\
\text { Croatia }\end{array}$ & $\begin{array}{l}8.35 \pm 2.19 \\
6.04 \pm 1.64\end{array}$ & 3.375 & $.002 * *$ & 2.3063 \\
\hline skinfold of the back & $\begin{array}{l}\text { Monten egro } \\
\text { Croatia }\end{array}$ & $\begin{array}{l}10.23 \pm 3.43 \\
10.29 \pm 3.24\end{array}$ & -.053 & .958 & -.0625 \\
\hline abdominal skinfold & $\begin{array}{c}\text { Monten egro } \\
\text { Croatia }\end{array}$ & $\begin{array}{l}14.83 \pm 6.93 \\
12.23 \pm 4.52\end{array}$ & 1.258 & .218 & 2.6000 \\
\hline upper leg skinfold & $\begin{array}{c}\text { Monten egro } \\
\text { Croatia }\end{array}$ & $\begin{array}{l}14.38 \pm 4.55 \\
11.40 \pm 2.90\end{array}$ & 2.208 & $.035^{*}$ & 2.9813 \\
\hline lower leg skinfold & $\begin{array}{c}\text { Monten egro } \\
\text { Croatia }\end{array}$ & $\begin{array}{l}9.19 \pm 3.58 \\
9.37 \pm 2.67\end{array}$ & -.157 & .877 & -.1750 \\
\hline body mass index & $\begin{array}{c}\text { Monten egro } \\
\text { Croatia }\end{array}$ & $\begin{array}{l}22.42 \pm 1.98 \\
21.94 \pm 1.93\end{array}$ & .695 & .492 & .4812 \\
\hline fat percentage & $\begin{array}{c}\text { Monten egro } \\
\text { Croatia }\end{array}$ & $\begin{array}{l}16.71 \pm 2.22 \\
15.47 \pm 1.63\end{array}$ & 1.798 & .082 & 1.2375 \\
\hline muscle mass & $\begin{array}{l}\text { Montenegro } \\
\text { Croatia }\end{array}$ & $\begin{array}{l}33.98 \pm 3.59 \\
36.56 \pm 2.61\end{array}$ & -2.325 & $.027 *$ & -2.5813 \\
\hline
\end{tabular}

$*-\mathrm{p}<.05 ; * *-\mathrm{p}<.01$ 


\section{DISCUSSION}

The aim of this study was to determine the difference in the body composition and anthropometric characteristics of the cadets (U15) water polo players of Montenegrin national team who won a silver medal at the European U15 water polo Championships in Burgas (Bulgaria) 21-28 July 2019, and of Croatian national team who occupied the eight position. The results were obtained by using a battery of 11 tests in the area of body composition and anthropometric characteristics. By looking into the basic descriptive statistical parameters, it can be concluded that we have examined the best selected cadet age water polo players from these two countries. Similar results in their research were obtained by Kondric' et al. (2012). It can be noticed that the water polo players of both national teams are of the approximately similar mean values of the some variables analyzed, which is not surprising because these are the two national teams of the same age, in countries where water polo is popular and in where water polo coaches are highly skilled. Water polo players U15 already have years of training experience, where they spend many hours in the pool during the week. However, the t-test results showed that the water polo players of both national teams differ significantly in the five variables analyzed, which is not surprising, compared to the results achieved at the European U15 water polo Championships in Burgas (Bulgaria) 2019. A statistically significant difference has been found in three variables that estimates subcutaneous fat: triceps skinfold, biceps skinfold $(\mathrm{p}<.05)$ and upper leg skinfold $(\mathrm{p}<.01)$, where the water polo players of Montenegro have a statistically higher value than the water polo players of Croatia. Also, water polo players of Croatian national team have a statistically higher value than the water polo players of Montenegrin national team in two variables that estimates body height $(p<.05)$ and muscle mass $(\mathrm{p}<.01)$.

For other variables, some values are better for water polo players of Montenegrin national team and some for water polo players of Croatian national team, although, insignificant for statistics. All mentioned indicates that water polo players of Montenegrin and Croatian national teams have some different body composition and anthropometric parameters. Based on the obtained results in this research, before the start of the European Championship in Burgas, it could be assumed that Croatian water polo players will score better than Montenegrin water polo players. Montenegrin water polo players had significantly higher levels of subcutaneous adipose tissue than Croatian water polo players, which is known to be a disruptive factor for athletes (Gardasevic et al., 2019a).
Also, in previous studies of water polo players of this age, subcutaneous adipose tissue has been shown to be a disruptive factor in defense (Milanovic \& Vuleta, 2013). It is well known that a low-fat percentage is desirable for high physical performance in all sports. Although, not every body composition characteristic is expected to play a role in optimal performance in professional sport, lower levels of body fat (that are specific to each player) are desirable for optimal performance as body mass must be moved against gravity (Rienzi et al., 2000; Gil et al., 2007).

In addition, Croatian water polo players had significantly higher value muscle mass than Montenegrin water polo players, and it is known how much water polo is a strenuous sport that takes place in water and how important the muscle mass is for water polo. Then, body height is important for swimming, long arms are important for kicks and defense. All that is surprising, considering that the Montenegrin national team played the final of the European U15 Championship and the Croatian national team dropped out in the quarter final of the competition, and the five analyzed variables significantly favored Croatian Water polo players. The reason for the better placement may be that Montenegrin water polo players had a higher level of technical and tactical preparation, functional and psychological than Croatian water polo players. Physical preparation at such championships is very important because it is played every day and we have not analyzed it.

Montenegrin and Croatian national water polo associations should turn to other research and check the functional-motoric status, psychological preparation as well as tactical training of their players and analyze if there are differecies in Montenegrin water polo players which influenced better results at this European championship, and whether there is room for improvement.The values obtained in this research can be useful for coaches of these national teams for making a comparison of their players with others and formulate their work in a way that enables reduction of those parameters that are not good, and raise those that are good to a higher level. That will surely make their water polo player performeance better and more successful. The results obtained in this research can serve as model parameters for the estimated variables for water polo players (U15) of all clubs in Montenegro and Croatia, because the players that have been analyzed here, were the best and the most successful water polo players in their countries, and participants in the European U15 Championship in Burgas (Bulgaria) 2019. 
GARDASEVIC, J.; BJELICA, D. \& VASILJEVIC, I. Diferencias en la composición corporal entre los jugadores de waterpolo de las selecciones nacionales de Montenegro y Croacia participantes en el Campeonato Europeo U15 2019. Int. J. Morphol., 38(3):720-725, 2020.

RESUMEN: El objetivo de esta investigación fue determinar las diferencias entre los jugadores cadetes de waterpolo (U15) de los equipos nacionales de Montenegro y Croacia en la composición corporal y las características antropométricas. Se dividió una muestra de 32 jugadeores en dos submuestras. La primera submuestra consistió en 16 jugadores de waterpolo del equipo nacional de Montenegro con una edad promedio de 14,69 $\pm 0,48$, los vicecampeones del Campeonato de Europa en Burgas (Bulgaria) 2019, mientras que la otra submuestra estuvo compuesta de 16 jugadores de waterpolo del equipo nacional de Croacia con una edad promedio de $14,75 \pm 0,45$, que ocuparon la octava posición en el Campeonato de Europa en Burgas (Bulgaria) 2019. Los jugadores de waterpolo fueron probados en los preparativos finales justo antes del campeonato europeo. La composición corporal y las características antropométricas se evaluaron mediante una batería de 11 variables: altura corporal, peso corporal, pliegue cutáneo del tríceps, pliegue cutáneo del bíceps, pliegue cutáneo de la espalda, pliegue abdominal, pliegue superior de la pierna, pliegue inferior de la pierna, índice de masa corporal, porcentaje de grasa y músculo masa. Se calcularon los parámetros estándar centrales y de dispersión de todas las variables. La importancia de las diferencias entre los jugadores de waterpolo de dos equipos nacionales en las variables para evaluar la composición corporal y las características antropométricas se determinó mediante una prueba t para muestras independientes. Se observó que existen diferencias estadísticamente significativas en cinco variables, en tres variables con $\mathrm{p}<0,01$ (altura corporal, pliegue de tríceps y pliegue de bíceps), y en dos variables con $\mathrm{p}<0,05$ (pliegue superior de la pierna y masa muscular). Los jugadores de waterpolo de Montenegro tienen pliegues cutáneos de tríceps estadísticamente significativamente más altos, pliegues cutáneos de bíceps y pliegues superiores de las piernas, y una altura corporal y masa muscular estadísticamente significativamente menor que los jugadores de waterpolo de Croacia.

PALABRAS CLAVE: Jugadores de waterpolo montenegrinos; Jugadores croatas de waterpolo; Composición corporal.

\section{REFERENCES}

Bjelica, D.; Gardasevic, J.; Vasiljevic, I.; Jeleskovic, E. \& Covic, N. Body composition and morphological characteristics of soccer players in Bosnia and Herzegovina. Kinesiol. Slov., 25(1):5-13, 2019.

Carvajal, W.; Betancourt, H.; León, S.; Deturnel, Y.; Martínez, M.; Echevarría, I.; Castillo, M. E. \& Serviat, N. Kinanthropometric profile of Cuban women olympic volleyball champions. MEDICC Rev., 14(2):16-22, 2012.

Gardasevic, J.; Akpinar, S.; Popovic, S. \& Bjelica, D. Increased perceptual and motor performance of the arms of elite water polo players. Appl. Bion. Biomech., 2019:6763470, 2019c.
Gardasevic, J.; Bjelica, D., \& Vasiljevic, I. Morphological characteristics and body composition of elite football players in Montenegro. Int. J. Morphol., 37(1):284-8, 2019a.

Gardasevic, J.; Bjelica, D.; Corluka, M. \& Vasiljevic, I. Elite football players from Bosnia and Herzegovina and Kosovo and their body composition. Sport Mont., 17(2):75-9, 2019b.

Gil, S. M.; Gil, J.; Ruiz, F.; Irazusta, A. \& Irazusta, J. Physiological and anthropometric characteristics of young soccer players according to their playing position: relevance for the selection process. J. Strength Cond. Res., 21(2):438-45, 2007.

Kondric, M.; Uljevic, O.; Gabrilo, G.; Kontic, D. \& Sekulic, D. General anthropometric and specific physical fitness profile of high-level junior water polo players. J. Hum. Kinet., 32:157-65, 2012.

Milanovic, D. \& Vuleta, D. Association between morphological dimensions of water polo players and play performance indicators. Sport Mont., 11(37-38-39):447-53, 2013.

Popovic, S.; Akpinar, S.; Jaksic, D.; Matic, R. \& Bjelica, D. Comparative study of anthropometric measurement and body composition between elite soccer and basketball players. Int. J. Morphol., 31(2):461-7, 2013.

Rico-Sanz, J. Body composition and nutritional assessments in soccer. Int. J. Sport Nutr., 8(2):113-23, 1998.

Rienzi, E.; Drust, B.; Reilly, T.; Carter, J. E. \& Martin, A. Investigation of anthropometric and work-rate profiles of elite South American international soccer players. J. Sports Med. Phys. Fitness, 40(2):1629, 2000 .

Corresponding author:

Jovan Gardasevic

University of Montenegro

Faculty for Sport and Physical Education

Narodne omladine bb, 81400 Niksic

MONTENEGRO

E-mail: jovan@ucg.ac.me

Received: 23-09-2019

Accepted: 03-01-2020 